\title{
HUBUNGAN ANTARA MINAT BACA DENGAN PRESTASI BELAJAR PADA MATA PELAJARAN PRODUKTIF DI SMK
}

\author{
Sabriyadi $^{1}$, Nana Sumarna ${ }^{2}$, Tatang Permana ${ }^{3}$ \\ Departemen Pendidikan Teknik Mesin \\ Universitas Pendidikan Indonesia \\ Jl. Dr. Setiabudhi No. 207 Bandung 40154 \\ sabri.yadi@yahoo.co.id
}

\begin{abstract}
ABSTRAK
Penelitian ini bertujuan untuk, mengetahui gambaran tingkat minat baca siswa pada mata pelajaran produktif, gambaran prestasi belajar siswa pada mata pelajaran produktif, serta besar nilai korelasi antara minat baca dengan prestasi belajar siswa pada mata pelajaran produktif di SMK. Metode yang digunakan dalam penelitian ini adalah, metode deskriptif studi korelasi, dengan pendekatan kuantitatif, serta teknik pengumpulan data berupa angket dan dokumentasi. Berdasar pada hasil pengolahan data, menunjukkan bahwa tingkat minat baca siswa SMK pada mata pelajaran produktif, termasuk dalam kategori sedang, dan prestasi belajar siswa pada mata pelajaran produktif, termasuk kedalam kategori sedang. Hasil pengujian korelasi antara minat baca dengan prestasi belajar pada mata pelajaran produktif, sebesar 0,5. Angka tersebut menunjukkan hubungan antara minat baca dengan prestasi belajar pada mata pelajaran produktif di SMK termasuk dalam kategori sedang serta memiliki hubungan yang positif.
\end{abstract}

Kata kunci: minat, prestasi, produktif, pembelajaran

\begin{abstract}
This study aims to, know the description of the level of student interest in reading on the productive subjects, an overview of student achievement in productive subjects, as well as the great value of the correlation between reading and academic achievement of students on productive in vocational subjects. The method used in this study is descriptive correlation study, the quantitative approach, as well as data collection techniques such as questionnaires and documentation. Based on the results of data processing, indicating that the level of interest in reading vocational students in productive subjects, including in the medium category, and student achievement in productive subjects, included into the category of being. Obtained by the correlation of test results between reading and academic achievement in productive subjects are 0.5 . The figure shows the relationship between reading and academic achievement in the subjects in vocational productive in medium category and has a positive relationship.
\end{abstract}

Keywords: interest, learning, achievement, productive, subject.

\footnotetext{
${ }^{1}$ Mahasiswa Departemen Pendidikan Teknik Mesin FPTK UPI

2 Dosen Departemen Pendidikan Teknik Mesin FPTK UPI

${ }^{3}$ Dosen Departemen Pendidikan Teknik Mesin FPTK UPI
} 


\section{PENDAHULUAN}

Sekolah Menengah Kejuruan (SMK), sebagaimana ditegaskan dalam Pasal 15 UU No. 20 Tahun 2003, bahwa pendidikan menengah kejuruan bertujuan untuk menyiapkan peserta didik terutama untuk bekerja dalam bidang tertentu. Siswa SMK diharapkan, mampu menguasai kompetensi yang diajarkan di sekolah, sehingga mampu melakukan pekerjaan, sesuai tuntutan dunia kerja. Prestasi belajar adalah hasil yang dicapai seseorang ketika mengerjakan tugas atau kegiatan tertentu. Selain itu prestasi belajar adalah penguasaan pengetahuan atau keterampilan yang dikembangkan oleh mata pelajaran, lazimnya ditunjukkan dengan nilai tes atau angka nilai yang diberikan oleh guru (Tu’u, 2004).

Seluruh siswa yang mengikuti UAS, hanya 38,5\% yang mampu mencapai standar kelulusan. Hasil ini menunjukkan bahwa, prestasi belajar siswa pada mata pelajaran produktif, masih belum maksimal. Faktor yang mempengaruhi prestasi belajar yaitu: faktor internal (faktor dari dalam diri individu), meliputi keadaan atau kondisi jasmani dan rohani siswa. Faktor eksternal (faktor dari luar diri individu), meliputi kondisi lingkungan sekitar siswa. Faktor pendekatan belajar (approach to learning) yaitu jenis upaya belajar siswa (kebiasaan), yang meliputi strategi dan metode yang digunakan siswa untuk melakukan keigatan pembelajaran materi pelajaran (Syah, 2008).

Salah satu faktor yang mempengaruhi prestasi belajar siswa adalah kebiasaan belajar. Satu kebiasaan yang penting dan tidak lepas dalam kegiatan belajar mengajar adalah membaca. Faktor yang penting dalam kegiatan membaca adalah adanya minat. Masyarakat yang gemar membaca memperoleh pengetahuan dan wawasan baru yang akan semakin meningkatkan kecerdasannya sehingga lebih mampu menjawab tantangan hidup pada masa mendatang. Salah satu kunci keberhasilan seseorang dalam meraih ilmu pengetahuan dan teknologi adalah dengan gemar/minat membaca (Rahim, 2007). Melihat adanya hubungan tersebut, hasil penelitian pendahuluan mengenai minat baca siswa khususnya pada mata pelajaran produktif, dengan kuisioner. Hasil yang didapat adalah, tingkat minat baca siswa SMK pada mata pelajaran produktif sebesar $28 \%$. Ukuran minat dapat dikategorikan menjadi minat tinggi (67-100\%), minat sedang (34-66\%), dan minat rendah (0-33\%).Hasil studi menunjukkan bahwa minat baca siswa SMK terhadap mata pelajaran produktif, masih tergolong dalam kategori rendah. Minat baca yang rendah ini, memungkinkan menjadi sebab 
masih belum maksimalnya prestasi belajar siswa. Uraian diatas menunjukkan adanya hubungan antara minat dengan prestasi belajar.

Penelitian ini betujuan untuk memperoleh gambaran minat baca dan prestasi belajar siswa pada mata pelajaran produktif. Memperoleh tingkat korelasi, antara minat baca dengan prestasi belajar siswa pada mata pelajaran produktif. Minat adalah kecenderungan yang tetap untuk memperhatikan dan menikmati beberapa kegiatan atau sesuatu (Slameto, 2003). Membaca sebagai upaya aktif pada pembaca untuk memahami pesan seorang penulis. Minat baca dapat diartikan adalah ketertarikan yang muncul dari dalam diri seseorang terhadap aktivitas membaca dengan penuh kemauan dan rasa senang (Zaif, 2011). Sehingga muncul dorongan untuk membaca dengan sendirinya, tanpa ada paksaan dan dengan sungguh-sungguh untuk mencapai tujuan dari membaca tersebut. Minat baca yang meningkat akan mempengaruhi sikap positif pada membaca. Prestasi belajar adalah suatu bukti keberhasilan belajar atau kemampuan seseorang siswa dalam melakukan kegiatan belajarnya sesuai dengan bobot yang dicapainya. Sangat baik menumbuhkan minat baca, karena dapat menumbuhkan kecerdasan dan meningkatkan daya imajinasi (Tarigan, 2011).

\section{METODE PENELITIAN}

Metode yang digunakan dalam penelitian ini adalah metode korelasional. Metode ini digunakan untuk menggambarkan minat baca dan prestasi belajar siswa. Pada penelitian ini korelasi digunakan untuk memperoleh hubungan dua variabel atau lebih, yakni sejauh mana variasi dalam satu variabel (minat baca) berhubungan dengan variasi dalam variabel lain (prestasi belajar).

Sampel dalam penelitian ini adalah siswa kelas XI TKR di SMK Negeri 8 Bandung tahun ajaran 2013-2014, dengan jumlah 213 siswa. Pengumpulan data yang digunakan dalam penelitian ini adalah angket dan dokumentasi. Instrumen telah divalidasi dan layak digunakan untuk mengumpul data. Sebelum data dianalisis, diubah dahulu ke dalam bentuk interval dengan menggunakan methods of successive interval (MSI). Persyaratan analisis data yaitu uji normalitas, uji homogenitas dan uji regresi linier sederhana. Pengujian hipotesis menggunakan uji koefesien korelasi dan uji keberartian regresi. 


\section{HASIL PENELITIAN}

Hasil pengujian persyaratan data yang meliputi uji normalitas, homogenitas dan regresi linier sederhana telah diperoleh sebagai berikut: data menunjukkan normal dan homogen. Sedangkan pengujian regresi diperoleh persamaan $\mathrm{Y}=28+0,4 \mathrm{X}$. Deskipsi data dari variabel membaca diperoleh sebagai berikut: sangat tinggi 3\%, tinggi 30\%, sedang 38\%, rendah $21 \%$ dan sangat $8 \%$. Deskipsi data dari variabel prestasi belajar diperoleh sebagai berikut: sangat tinggi $3 \%$, tinggi $26 \%$, sedang $41 \%$, rendah $21 \%$ dan sangat $8 \%$. Hasil pengujian korelasi kedua variabel diperoleh hasil sebesar 0,49 atau masuk dalam kategori sedang.

\section{PEMBAHASAN}

Hasil yang diperoleh dari penelitian menunjukkan bahwa minat baca siswa pada mata pelajaran produktif. Hasil dari 66 siswa yang menjadi sampel, rata-rata minat baca siswa sebesar 38\%. Hal tersebut masuk dalam kategori sedang. Artinya minat baca siswa belum menggemberakan pada mata pelajaran produktif. Sehingga hal ini perlu ditngkatkan lagi sampai menjadi lebih baik. Minat baca sangat penting untuk menunjang siswa dalam menggapai prestasi yang tinggi. Dibutuhkan strategi, sarana dan prasaran untuk mendongkrak minat baca siswa. Salah satu upaya yaitu menambah jumlah referensi di perpustakan, buku paket dan modul.

Prestasi belajar siswa yang diteliti adalah nilai UAS. Hasil penelitian terhadap 66 siswa yang menjadi sampel penelitian, didapat hasil rata-rata pretasi siswaya, yaitu $41 \%$, dan termasuk dalam kategori sedang. Prestasi belajar siswa mata pelajaran produktif cukup baik. Prestasi belajar ini tentu dipengaruhi oleh berbagai faktor, yaitu: keadaan atau kondisi jasmani dan rohani, lingkungan, pendekatan belajar (approach to learning), kebiasaan belajar dan strategi dan metode belajar.

Prestasi belajar dapat dipengaruhi oleh faktor internal, eksternal, dan pendekatan belajar. Sehingga tiap perubahan baik itu peningkatan, maupun penurunan faktor-faktor tersebut akan berdampak terhadap prestasi belajar. Hasil penelitian diketahui, koefisien regresi untuk minat baca sebesar 0,4 , nilai koefisien korelasi terhadap prestasi belajarpada mata pelajaran produktif sebesar 0,9 , dan memiliki nilai $t_{\text {hitung }}$ sebesar 4,4 melebihi nilai $t_{\text {tabel }}$ sebesar 1,7. Hasil tersebut dapat diartikan bahwa minat baca berpengaruh positif dan signifikan dengan prestasi belaja. Hasil dari koefesien korelasi yakni sebesar 0,49 termasuk ke dalam 
kategori sedang. Hasil ini menggambarkan bahwa, minat baca dengan prestasi belajar siswa pada mata pelajaran produktif, memiliki hubungan yang mmasih belum menggembiakan atau belum kuat. Sehingga perlu ditingkatkan lagi.

Kebiasaan belajar merupakan salah satu faktor yang mempengaruhi prestasi belajar. Kebiasaan belajar yang baik salah satunya adalah membaca. Kebiasaan yang mempengaruhi belajar antara lain pembuatan jadwal dan pelaksanaannya, membaca dan membuat catatan, mengulangi bahan pelajaran, konsentrasi dan mengerjakan tugas (Slameto, 2003). Menumbuhkan kebiasaan membaca, perlu adanya minat baca. Hasil tersebut menunjukkan bahwa, minat baca bukan merupakan satu-satunya faktor yang mempengaruhi prestasi belajar, Faktor minat baca cukup mempengaruhi prestasi belajar siswa, dan perlu adanya perhatian. Salah satu kunci keberhasilan seseorang dalam meraih ilmu pengetahuan dan teknologi adalah dengan gemar/minat membaca (Cullinan, 2000). Pendapat-pendapat tersebut menggambarkan bahwa, minat baca berhubungan dengan prestasi belajar. Minat siswa terhadap bahan bacaan khususnya pada mata pelajaran produktif, membuat siswa termotivasi untuk terus menggali ilmu dari bahan bacaan tersebut. Kepuasan yang didapat dari hasil membaca, baik berupa ilmu, maupun nilai pada mata pelajaran tersebut. Siswa harus terus menambah ilmu dari membaca, tanpa ada paksaan dari orang lain. Kegemaran ini diharapkan menjadikan salah satu kunci keberhasilan atau prestasi belajar siswa.

\section{KESIMPULAN}

Minat baca siswa pada mata pelajaran produktif termasuk dalam kategori sedang, sehingga belum cukup untuk mengdongkrak prestasi. Prestasi belajar siswa termasuk dalam kategori sedang. Artinya sebagian besar siswa memiliki prestasi belajar belum cukup baik dalam mencapai prestasi tertinggi pada mata pelajaran produktif. Hubungan kedua variabel positif antara minat baca dengan prestasi belajar, secara simultan dapat ditingkat bersamasama.

\section{DAFTAR PUSTAKA}

Cullinan, B.E. (2000). Independent Reading and School Achievements. Library Media Research. Journal of the American Association of School Librarians. 3 (1523-4320), p.1-24. 
Rahim, F. (2007).Pengajaran Membaca Di Sekolah Dasar. Jakarta: Bumi Aksara.

Slameto. (2003). Belajar dan Faktor-Faktor yang mempengaruhinya. Jakarta: Rineka Cipta.

Syah, M. (2008). Psikologi Pendidikan dengan Pendekatan Baru. Bandung: Remaja Rosdakarya.

Tarigan, H.G. (2011). Membaca dalam Kehidupan. Bandung: Angkasa.

Tu’u, T. (2004). Peran Disiplin pada Perilaku dan Prestasi Siswa. Jakarta: Grasindo.

Zaif, A. (2011). Minat Baca Siswa. [Online]. Tersedia di: http://zaifbio.wordpress.com /2011/11/21/minat-baca-siswa/. Diakses 12 Maret 2014. 